\title{
PV Array Based Smart Home Automation System
}

\author{
A. Şenpınar
}

\begin{abstract}
The utilization of renewable energy sources have been increasing day by day. Solar, wind, biomass, wave, etc. are some of the renewable energy sources. Solar, wind and hydro are more commonly used than others. Solar energy has many advantages such as abundance, renewability, continuation, and pollution free etc. Advancing technology increases people's life standards. Over time, high life standards have stopped being a luxury and entered people's homes with smart home automation systems. With the advances in Internet technologies, people now expect to be able to control their homes and workplaces over the Internet too. This study controls six different Computer/Internet-based systems of smart home automation in a house which is included solar arrays. These systems were illumination of three different rooms, temperature control of a room, garden irrigation system control, and home security system control. With the software written, all these systems were monitored online on a website. These controls were successfully experimented on the model house with the smart home automation system designed.
\end{abstract}

Index term-- Internet access, pv arrays, renewable energy, smart home automation.

\section{INTRODUCTION}

$\mathrm{H}$ UMAN needs are changing increasingly by the day along with the advancing technology. Millions of engineers and scientists around the world are working towards achieving these advances. Recent human needs entail the facilitation of home and work life. Many previously manual operations can now be performed automatically with the automation systems developed with the help of advancing technology. Such efforts are known by the name "Smart Home Automation Systems". The main goal of this concept is to enable a safer, easier, more comfortable and economic life. The energy consumption has been also increasing since these systems are increasing. So, it is utilized from renewable energy sources to meet the energy.

Commonly used methods in smart home automation systems include phone control, internet based control, Plc control and computer control.

Even though smart buildings were defined for the first time at the beginning of the 1980s in the USA, it only reached Turkey in 1984. At first, applications in the country were based on observation. Many applications around this time and thereafter targeted the comfort of healthy and ordinary people. Yumurtaci et al. studied smart home systems and the technologies usually used in these systems [1].

A. SENPINAR, is Department of Electronics Technology, College of Technical Sciences, Firat University, Elazig, Turkey, (e-mail: asenpinar@gmail.com).

Manuscript received May 03, 2018; accepted June 30, 2018.

DOI: $10.17694 /$ bajece. 420722
Yet another study designed a smart home automation system over GSM technology. This technology works over a phone line by processing digitized tones, and has the advantage of being used independently of time and place.

Isik et al. used a different method to design another mobile phone based smart home automation system [2]. Bekcibasi and Tenruh studied control over telephone and concluded that it may be preferred owing to its ease and reasonable maintenance costs [3]. There are many other studies on GSM technology [4-8]. For Internet control, the design is made with a server card embedded into the web interface and accessing the system over the Internet [9-12]. Other researchers studied computer controlled smart home automation systems. In this method, control is achieved via the interface program on a desktop or laptop computer by accessing micro-controlled circuits over ports [13-14]. Smart home systems designed for Plc control operate by accessing the Plc over a written Scada [15]. There are also other studies on smart home automation systems, most of which used micro controller design [16-17]. Other researchers have investigated the general structure of smart home automation systems [18-30]. Hazer et al. studied the control parameters and benefits of smart home automation [31]. Some researchers have investigated the renewable energy and energy systems of smart home automation systems [32, 33].

Smart home automation systems may be used to control electronic tools and systems such as security [34, 35], temperature [36, 37], RF command [38, 39], illumination [40], TV, sound systems, irrigation systems, curtain control, and garden/garage gate control. These systems may particularly benefit disabled and old people's lives.

When people are away from their homes, they wish to control what is happening over smart home automation systems. For instance, having left for their summer vacation, a family may want to check their home security system or irrigation for the garden from afar. Similarly, a family may want to check the temperature at home on the internet and adjust it before they arrive home after an evening out. This study aims to enable the control of different home electronic systems by means of renewable energy sources away from home. The energy which is required for this purpose is provided by $\mathrm{pv}$ array. These systems controlled via a computer were the illumination of three rooms, temperature control of a room, home security system control, and the control of garden irrigation system.

\section{SYSTEM DESIGN}

The designed smart home automation system was accessed over the internet. The system basically works over a computer program. System information is entered on a database through a website. This database is kept on a rental server. 
The computer program reads and transmits data regularly from the database to the control circuit. There are six active outputs from the computer in the system. These outputs are used to illuminate three rooms, start and stop air conditioning for temperature in a room, start and stop the garden irrigation system, activate and stop the home security system. Optionally, the number of outputs can be increased; any device on a power line, for instance an iron, tv, or electric oven may be controlled. The designed system has 8 outputs and six of them are ready for active use. Further, the system may also be used to control the temperature of three rooms. Another feature on the system is that it allows the eight input unit to be checked over a website. The system is not affected by power outages because it is supported by pv arrays. Fig. 1 shows the block diagram of the designed system. Fig.2 shows the model house where the designed smart home automation system could be established. The designed system has five main components: pv array, internet access, computer software program, control circuit and driver circuit.

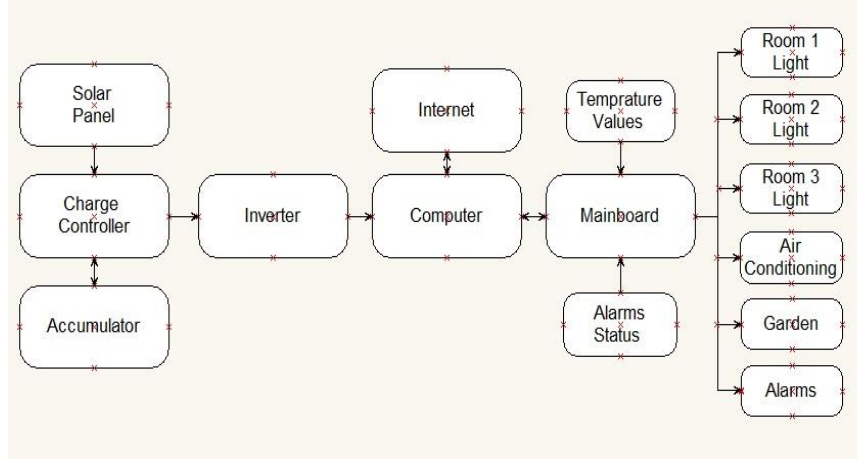

Fig. 1. Block diagram of the designed system

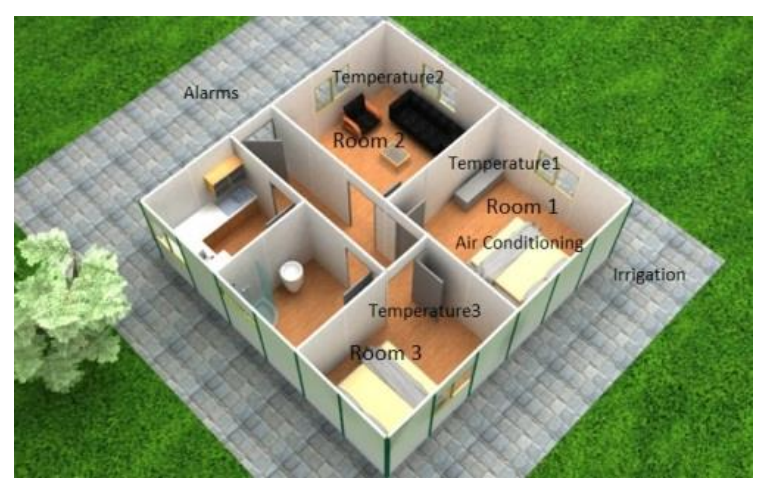

Fig.2. Model house

\section{A. Pv Array}

A PV cell is a specialized semiconductor material with a $\mathrm{p}-$ $\mathrm{n}$ junction. It converts sunlight into electricity through a basic process called photovoltaic effect. The energy generated by the cell is in direct proportion with the visible light it has been exposed to. Additionally, conversion efficiency also depends on extending the plane. The amount of the current and the voltage changes depending on the amount of sunlight shining on the cell. Then, the I-V equation is:

$$
\mathrm{I}=\mathrm{I}_{1}-\mathrm{I}_{0}\left(\mathrm{e}^{(\mathrm{qV}) /(\mathrm{kT})}-1\right)
$$

where $I_{1}$ is the component of the pv cell current due to photons, electrical load $\left(\mathrm{q}=1,6 * 10^{-19} \mathrm{C}\right), \mathrm{k}=1,38 * 10^{-23} \mathrm{j} / \mathrm{K}$ (Boltzman constant) and $\mathrm{T}$ is the cell temperature in Kelvin.

\section{B. Internet Access}

Internet access enables remote access to the system. It allows people to control their smart home automation system by using a predefined website. As the website supports mobile devices, the system may also be accessed over smart phones. Website design has two components. The first one entails the inclusion or exclusion of the electronic devices or systems to be controlled. The buttons here are used to switch on/switch off. The first component shows the current temperature in a pre-specified room on the screen. Based on this temperature, the user can control the air conditioning system for heating in winter or cooling in sun. Buttons in the second line in Fig.3 are used to switch on/switch off for garden (irrigation), air conditioning (rooms) and home security. The second component includes the activation/deactivation of the home security system. When an alarm goes off while the security system is in use, this component notifies us and provides see on the screen from website. Buttons in the last line in Fig.3 show the alarm statuses. For example; when the alarm conditions are active, it turns red from green. Fig. 3 shows the web page.
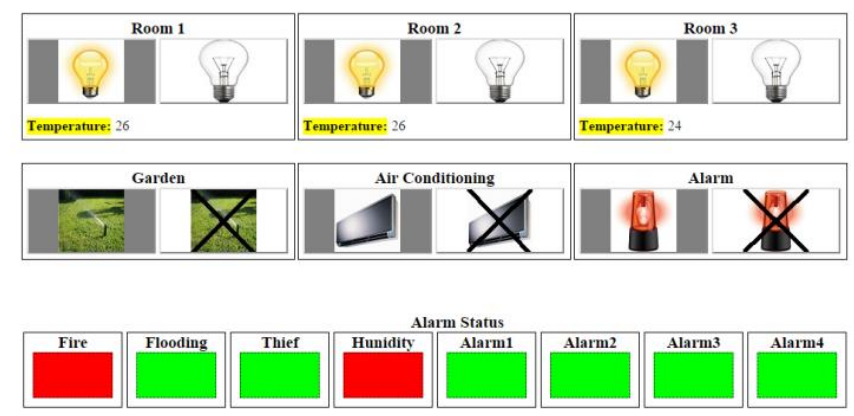

Fig.3. Web page

\section{Computer Software Program}

The computer software program is a desktop application using the RS-232 series communication that controls the designed system. Fig. 4 shows the flow chart of it. This application provides the connection between the internet site and the control circuit. Owing to this program, the devices on the smart home automation system may be controlled over the home computer when there is no internet. Below is a screenshot from when the application runs for the first time (Fig.5).

This application has two sections. The first one includes the settings for the connection between the application and the control circuit. The COM port to connect to and the speed for the connection are selected here. When the COM port is clicked, currently usable ports are displayed. If the port that our device has been connected to is not shown among the ports, the connection between the port and the electronic circuit needs to be checked. The second section is where the devices on the system can be checked. It has been designed to check 6 devices and includes 12 buttons for the switch on/switch off operations. The left side of the dual buttons is used for energizing, and the right side for de-energizing. All buttons have active and passive positions. 
BALKAN JOURNAL OF ELECTRICAL \& COMPUTER ENGINEERING， Vol. 6, No. 3, July 2018

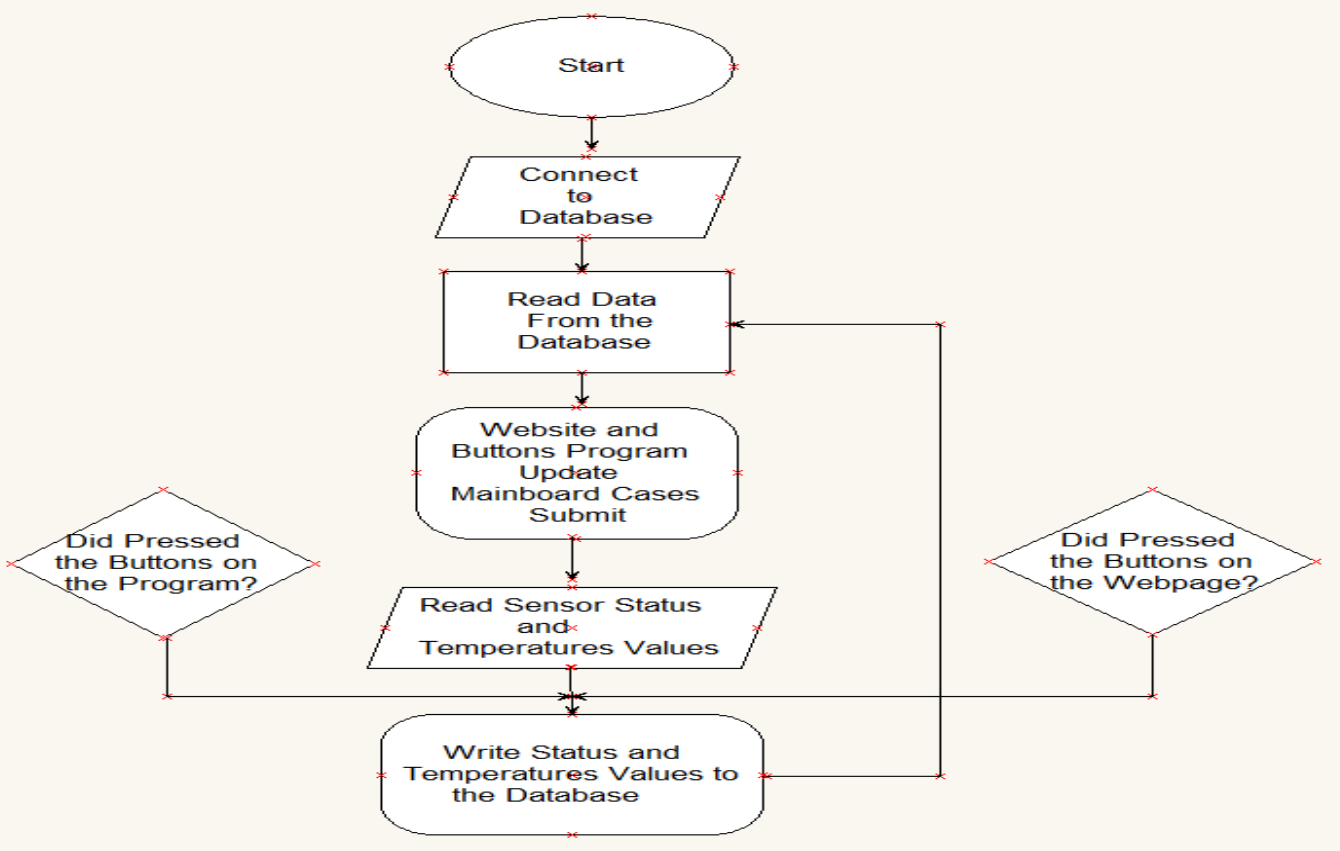

Fig.4. The flow chart of desktop application

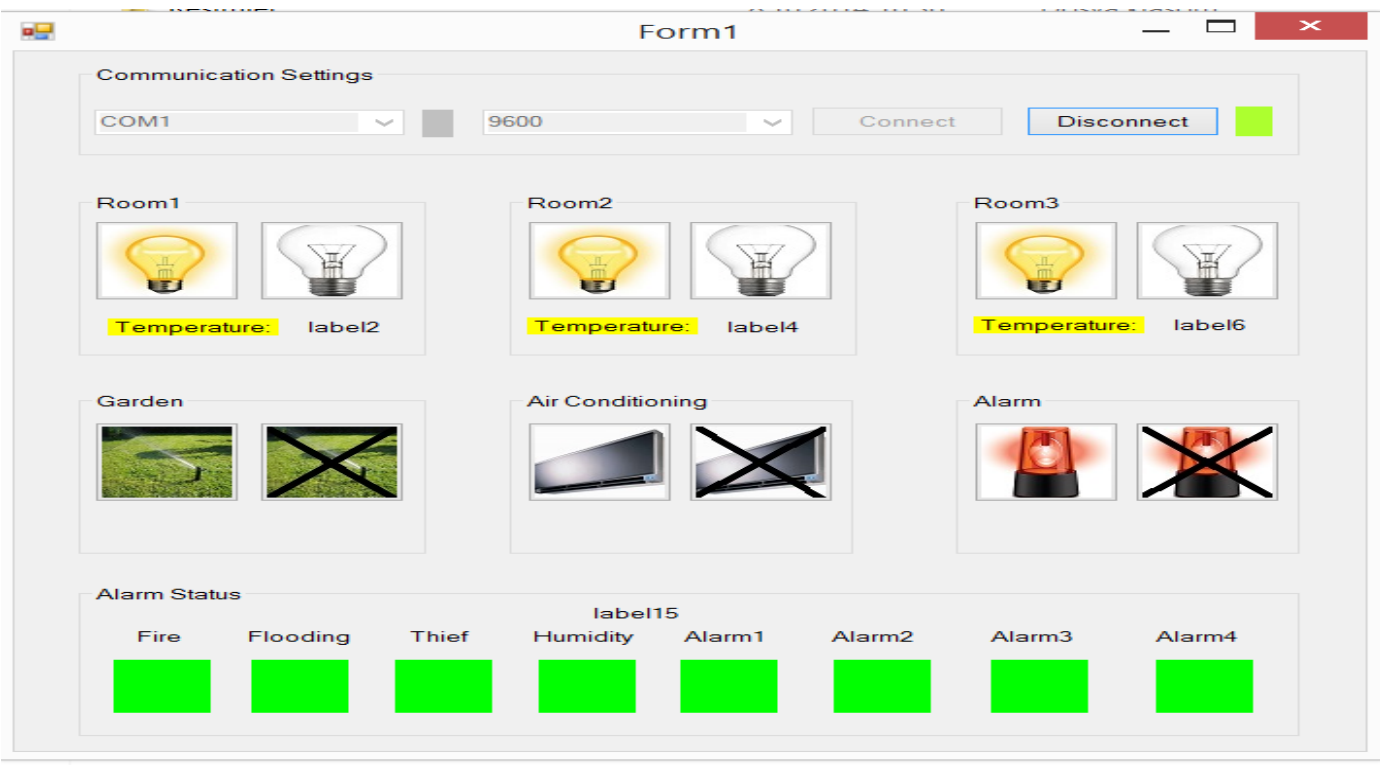

Fig.5. Screenshot of the desktop application

These positions provide information about whether that device is working online or not. This enables us to view the device that we wish to control and change its position accordingly. In addition, the temperature values of the rooms can also see in this section if want.

\section{Control Circuit}

The control circuit is the unit that enables communication between the computer and the devices to be controlled. This circuit is connected to the computer output and controls the driver circuit according to the commands received. At the same time, it sends the information from the security system and the value from the temperature sensor to the computer.
The microprocessor used was Microchip's 16F877A from the PIC family. This microprocessor has enough input/output ports for the controls. It also enables the RS-232 series communication protocol that the system requires to communicate with the computer.

The system has 6 active outputs and has been designed to control up to 8 outputs with the same design. All controls made over the computer application can be viewed simultaneously on the website designed. In other words, the designed $\mathrm{pv}$ array based smart home automation system may be controlled both from a distance over the website and from home computer. The control circuit diagram and card are shown in Fig.6. 

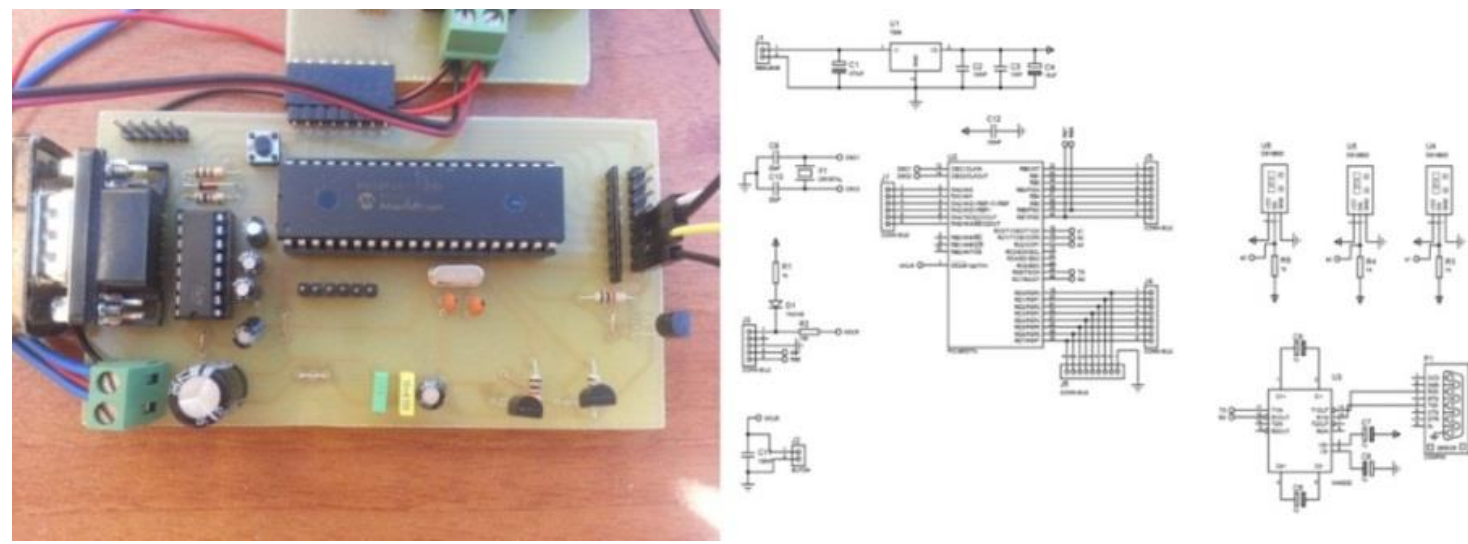

Fig.6. Control circuit diagram and card
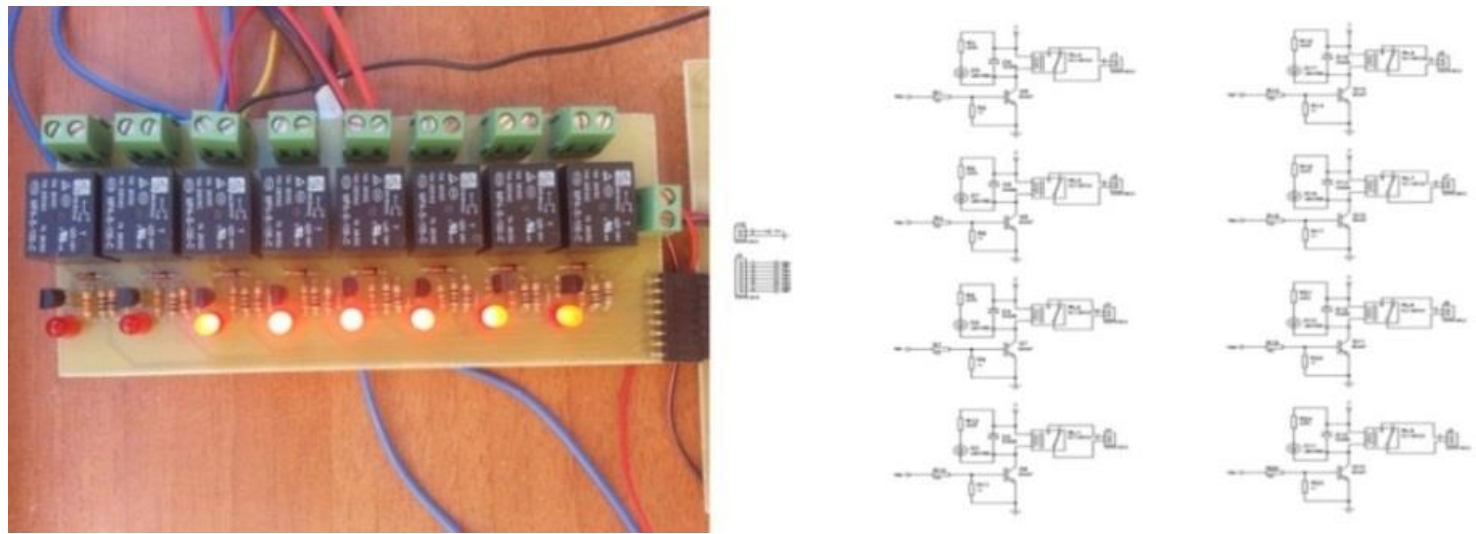

Fig.7. Driver circuit diagram and card

\section{E. Electronics Driver Circuit}

The electronics driver circuit is used to switch on and off the loaded devices depending on logic- $1(+5 \mathrm{~V})$ and logic- 0 (GND) from the control circuit. It has a relay and a transistor. The transistor provides the energy needed for the relay by elevating according to the logic information received. With the led connected to the circuit, it may be understood whether the driver is active or passive. This circuit was designed as a model to control only one output. The system has 6 active outputs and so six leds in Fig.7 are active. It can be increased to control up to 8 outputs with the same design if needs.

For every other output, the circuits can be multiplied. Below is a diagram and complete state of a driver circuit for controlling a device (Fig.7).

\section{F. The Input Units of System}

The input units of the system are those that transmit any alarm incidents to the control card when the alarm output is active. The designed circuit supports eight alarm incidents. During the experiments, 4 active alarm inputs were used. These were as follows:

\subsection{Humidity Sensor}

The sensor used in the system measures humidity and yields an appropriate analog output. The output signal is between 0 $5 \mathrm{~V}$. This sensor is used with a comparator circuit. With the help of a potentiometer on the circuit, the desired humidity level is set. If the humidity level increases this pre-specified level, the circuit yields logic-1 information. Afterwards read with a microprocessor, this information is shown in the computer software and the Internet site.

\subsection{Fire Sensor}

The fire sensor in the system is one that yields analog output by perceiving ultraviolet (UV) light. It is used with a comparator circuit. With the help of a potentiometer on the circuit, the desired fire level is set. If the fire level in the environment increases this at any given time, we are informed over the computer and the website via the microprocessor.

\subsection{Motion (PIR) Sensor}

Known as the PIR sensor, this motion sensor yields $3 \mathrm{~V}$ digital output based on the motion level. For as long as motion exists and depending on the time set, this $3 \mathrm{~V}$ output continues. When there is no motion, the output is $0 \mathrm{~V}$. As the microprocessor does not perceive $3 \mathrm{~V}$ as logic, an additional logic inverter has been used in the circuit between output and the microprocessor.

\subsection{Flooding Sensor}

The sensor functions on dry contact logic. It has two ends. One is connected to the feeding voltage. The other is connected to the microprocessor. If the water level rises, the sensor closes its contacts and thus logic-1 is fed into the microprocessor. 
BALKAN JOURNAL OF ELECTRICAL \& COMPUTER ENGINEERING， Vol. 6, No. 3, July 2018

\section{EXPERIMENTAL APPLICATION}

The designed smart home automation system may be controlled over a website or the computer depending on the user's preference. A laptop was used to put this system into use. First, pv array and charge regulator are connected to system. Then, the energy needed for the system is met by them. To begin with, the desktop application was downloaded on the laptop. Following this, connection was established between the control and driver circuits and the computer. Finally, the loads we planned to control were connected to the driver circuit and the system was ready to be used. The overview of the experimental system can be seen in Fig.8.

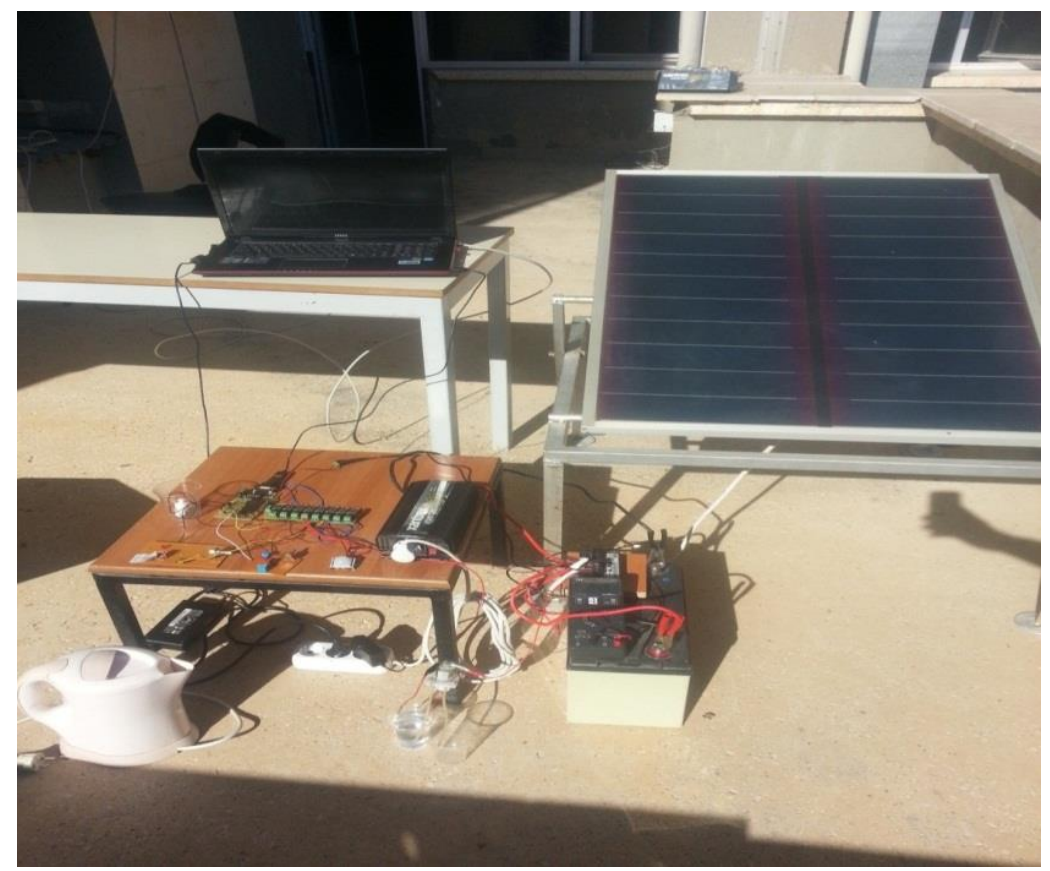

Fig.8. Overview of the experimental system

In order to run the smart home automation system, the desktop application was operated to observe the temperature data and alarm status from the control circuit. Then, a personal website was reached from the computer to observe the change in the alarm status connected to the security system in the circuit. The alarm indicator that is normally is green turns red if the alarm is activated. The changes in room temperature at different times can be observed from the internet page (Fig.9).
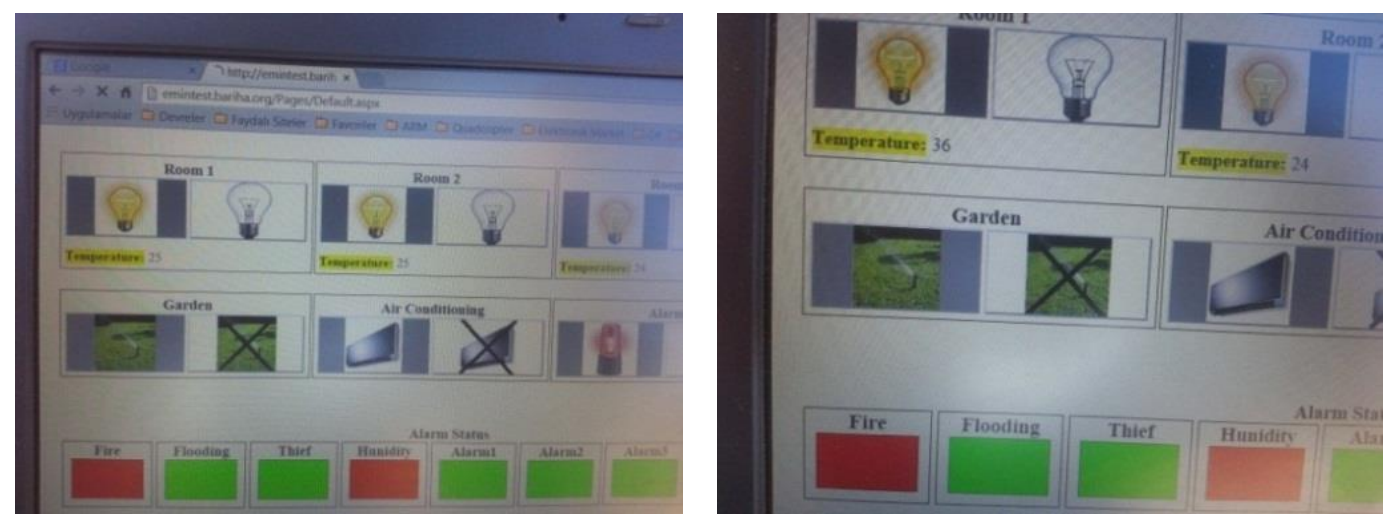

Fig. 9 Changes in temperature 
BALKAN JOURNAL OF ELECTRICAL \& COMPUTER ENGINEERING， Vol. 6, No. 3, July 2018

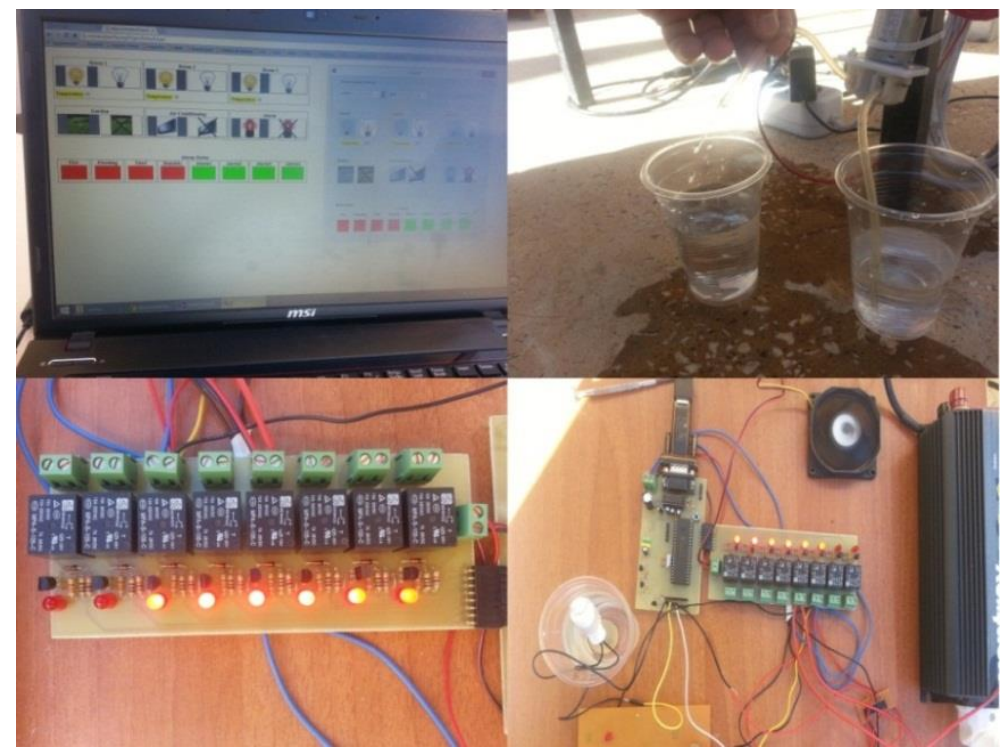

Fig.10. Observation of led and loads with all active output

When all outputs are active, the 6 led lights on the driver card give off light. The small computer fan representing the air-conditioning system keeps working, and the water pump representing the irrigation system moves the water in the glass (Fig.10).

When a load at an output is active, the led connected to that output is on (Fig.11). This shows whether an output is active or passive. When will outputs are active as above, all of the 6 different controls on the smart home automation system may be made: illumination of 3 rooms, temperature (airconditioning) control in one room, garden irrigation system control, and home security system control.

As input to the system, four active inputs were tried. The changes in the website and desktop application were observed online by boiling water in a kettle and applying vapor on the humidity sensor, by bringing a lighter close to the fire sensor, by moving a hand in front of the motion sensor, and by pouring water into a glass with the flood sensor in it (Fig.11).

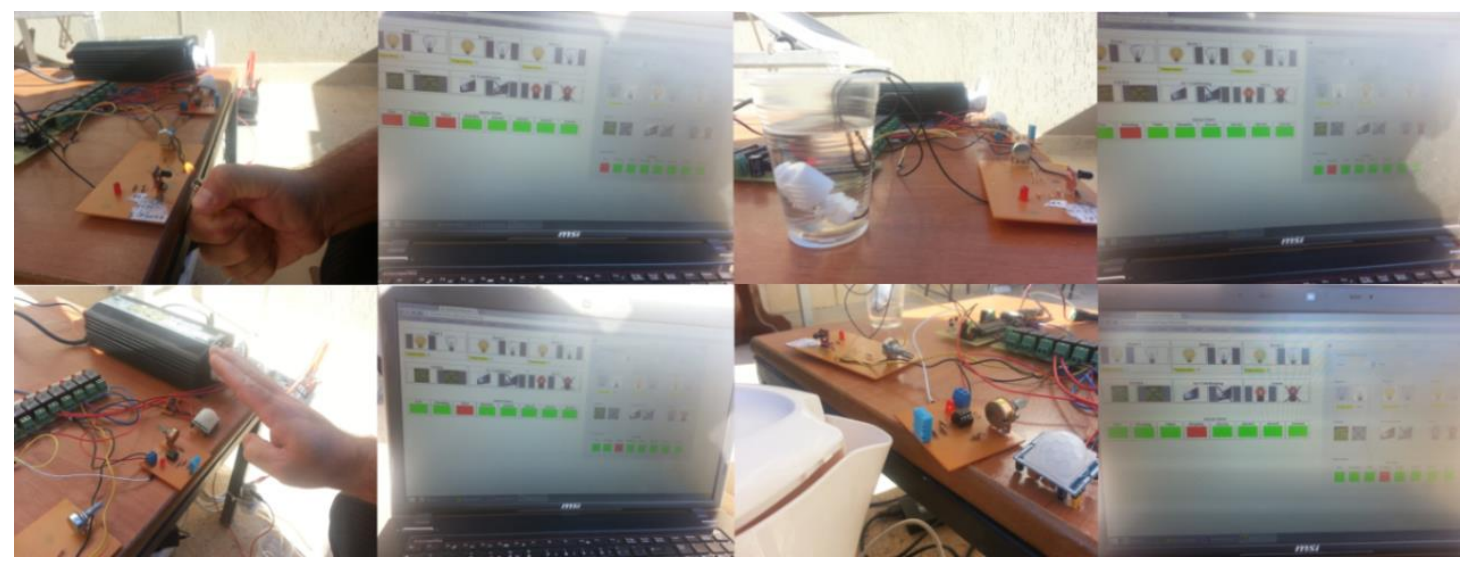

Fig.11. Observation of input units

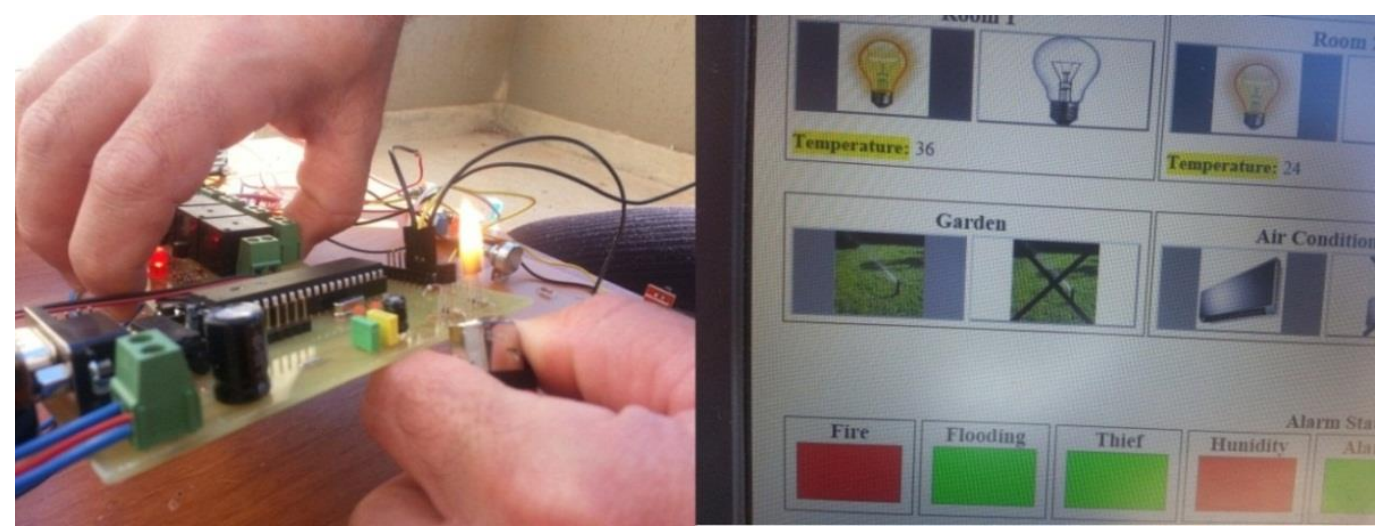

Fig.12. Observation of temperature changing 
In addition, the temperature change that occurred when one of the room temperature sensors was heated with a lighter was observed instantly on the website and the desktop application (Fig.12).

The designed smart home automation system has been also supported by renewable energy sources, such as pv array. That is why the energy consumption needed for the control and driver cards in the system is approximately $5-10 \mathrm{~W}$. The energy consumption of a laptop computer controlling these is approximately between $60-70 \mathrm{~W}$. The modem for the internet connection also consumes an average of $5 \mathrm{~W}$, thus necessitating a total of approximately $80-100 \mathrm{~W}$ energy consumption. As can be seen, the energy required for the system may be provided by a $100 \mathrm{~W}$ solar panel. In this experiment, the pv array for $80 \mathrm{~W}$ was been used.

\section{CONCLUSION}

The use of solar energy in building is one important contribution for the reduction of fossil fuel consumption and harmful emissions to the environment. Solar energy used for industrial processes is an inevitable trend in future. Solar energy is clean and safe in many industrial sectors. This study focused on using the internet to control the illumination system, temperature system, irrigation system, and security system for pv array based smart home. It is an advantage of the designed smart home automation system that it may be controlled both over a website and with a computer. The reasonable costs of the automation system and its ease of application are the other advantages. This system facilitates human life. The designed smart home automation system can be applied to a small model house in future works.

Future studies may regularly record home controls and temperature information in graphics. This would enable an observation of how long a device works daily and how much energy they consume on average. The system may also be made more useful by add on such as mobile device software and RF command.

\section{REFERENCES}

[1] M.Yumurtacı ve A.Keçebaş, "Akıllı Ev Teknolejileri ve Otomasyonu Sistemleri”, 5. (IATS'09), 13-15, Karabük, Türkiye, Mayıs 2009.

[2] Işı, Hakan, ve A. Alpaslan Altun, "Mikrodenetleyici Kullanılarak Cep Telefonu Kontrollü Akıllı Ev Uygulaması."

[3] U.Bekçibaşı ve M.Tenruh, "Telefon Şebekesi Üzerinden Şifre GüvenlikliAkıllı Ev Kontrol Sistemi”, 13.( Akademik Bilișim'11), 24, Malatya, Şubat, 2011

[4] K.İnan ve M.Ali Akçayol, "GSM Tabanlı Akıllı Ev Uygulaması", Bilişim Teknolojileri Dergisi, Cilt: 2, Sayı: 2, Mayıs 2009.

[5] B.Cincirop, "Gsm Kontrollü Akıllı Ev Otomasyonu", Sakarya Üniversitesi Elektronik ve Bilgisayar Eğitimi Yüksek Lisans Tezi, 2009.

[6] T.Aydoğan, A.Çakır, M.A.Akça ve Y.E.Polat, "Telefonu İle Çağrı Otomasyonu".

[7] C.Can, A.İpek, E.Azapoğlu ve R.O.Türker, "Lazer Güvenlik Sistemi ve Gsm Haberleșme”, MYO-OS 2010- Ulusal Meslek Yuksekokulları Oğrenci Sempozyumu.

[8] İ.Çayıroğlu ve S.Görgünoğlu, "Mobil Telefon ve Pic Mikrodenetleyici Kullanarak Uzaktan Esnek Kontrol Sağlanması", Int.J.Eng.Research\&Development,Vol.2,No.1, January 2010.

[9] O.Tosunoğlu ve M.Göktürk, "Akılll Ev Sistemlerinde Ethernet Üzerinden Cihaz Kontrolü Ve İzlenmesi”, ELECO'2008, ElektrikElektronik-Bilgisayar Mühendisliği Sempozyumu ve Fuarı.

[10] F.Kahraman ve A.F.Boz, "Web Tabanlı Otomasyon Sistemi Tasarımı ve Yapımı”, 5. (IATS'09), 13-15, Karabük, Türkiye, Mayıs 2009.
[11] S.T.Bushby, BACnet: a standard communication infrastructure for intelligent buildings, Automation in Construction 6 (1997) 529-540.

[12] A.Kaklauskas, E.K. Zavadskas, Internetinè sprendimų parama (Webbased decision support), monograph, Technika, Vilnius, 2002, 216 pp. [in Lithuanian].

[13] İ.Yabanova, S.Taşkın, H.Ekiz ve H.Çimen, "Denetleyici Alan Ağı Üzerinden Mekatronik Bir Sistemin Kontrolü”, Makine Teknolojileri Elektronik Dergisi, Cilt: 7, No: 2, 2010.

[14] L.Birgül ve G.Cansever, "Mikrokontrollör ile Akıllı Ev Otomasyonu ve Bilgisayar Arayüzü”, ELECO'2008, Elektrik-ElektronikBilgisayar Mühendisliği Sempozyumu ve Fuarı.

[15] U.Bayram, "Akıllı Ev Otomasyonu", Çanakkale Onsekiz Mart Üniversitesi Bilgisayar Bölümü Yüksek Lisans Tezi, 2006.

[16] G.Arslanoğlu, "Rf Ev Otomasyonu", Gazi Üniversitesi ElektrikElektronik Mühendisliği Yüksek Lisans Tezi, 2009.

[17] H.Korkmaz, "Akılll Ev Otomasyonunun Mikrodenetleyici ile Gerçekleştirilmesi”, Yıldız Teknik Üniversitesi Elektrik Mühendisliği Yüksek Lisans Tezi, 2007.

[18] F.Cem Uzun, "Akıllı Binalarda Otomasyon”, Makine Mühendisliği Yüksek Lisans Tezi, 2009.

[19] M.T.Gençoğlu, "Akıllı evler", I.Mühendislik ve Teknoloji Sempozyumu (2008), pp.221-234.

[20] A.Kaklauskas, E. Zavadskas, R. Ditkevičius, An intelligent tutoring system for construction and real estate, Lecture Notes in Computer Science, 4101, (2006), pp1.74-181.

[21] J.-H. Park, H.-S. Park, S.-J. Lee, J. Choi, D.-G. Lee, Intelligent multimedia service system based on context awareness in smart home, Lecture Notes in Computer Science, 3681, (2005), pp.11461152.

[22] K.Schacht, New developments: smart materials (cutting edge, shapememory properties, column), Appliance Manufacturer, 52, (1), (2004),pp. 14-16

[23] T.Staedter, The smart antenna (Visualize, brief article), Technology Review Cambridge, 106, (1), (2003),pp. 81-82.

[24] J.Wong, H. Li, J. Lai, Evaluating the system intelligence of the intelligent building systems: Part 1: development of key intelligent indicators and conceptual analytical framework, Automation in Construction, 17, (3), (2008), pp. 284-302.

[25] H.W. Kua, S.E. Lee, Demonstration intelligent building - a methodology for the promotion of total sustainability in the built environment, Building and Environment, 37, (3), (2002),pp.231-240.

[26] J.K.W. Wong, H. Li, S.W. Wang, Intelligent building research: a review, Automation in Construction, 14, (1), (2005),pp.143-159.

[27] J.Neelamkavil, Automation in the prefab and modular construction industry, 2009- 26th International Symposium on Automation and Robotics in Construction (ISARC 2009) Austin, Texas, USA, June 24-27, 2009, pp. 299-306.

[28] Z.Chen, D. Clements-Croome, J. Hong, H. Li, Q. Xu, A multicriteria lifespan energy efficiency approach to intelligent building assessment, Energy and Buildings, 38, (5),(2006),pp.393-409.

[29] H.Arkin, M. Paciuk, Evaluating intelligent building according to level of service system integration, Automation in Construction, 6, (1997),pp.471-479.

[30] J.Naimavičienė, Intelligent knowledge and device based assisted residential environment: doctoral dissertation: technological sciences, civil engineering (02T), Vilnius Gediminas Technical University, Technika, Vilnius, (2008), pp.134

[31] H.Şahin ve O.Hazer, "Akıllı Konut Teknolojileri”, Gazi Üniversitesi Endüstriyel Sanatlar Eğitim Fakültesi Dergisi, Sayı:269, Mayıs 2010.

[32] G.Wood, M. Newborough, Energy-use information transfer for intelligent homes: enabling energy conservation with central and local displays, Energy and Buildings, 39, (2007),pp.495-503.

[33] A.M.Omer, Renewable building energy systems and passive human comfort solutions. Renewable and sustainable, Energy Reviews, 12, (6),(2008),pp.1562-1587.

[34] D.W.Seward, S.D. Quayle, System architectures and safety for mobile construction robots, 13th Int. Symp. on Robotics in Construction, Tokyo, Japan, June 1996, pp. 727-732.

[35] C.Soungho, K. Naruo, Application of location information by stereo camera images to project progress monitoring, ISARC 2007, September 2007, 24th International Symposium on Automation and Robotics in Construction, Indian Institute of Technology Madras, Kochi, India, September 2007, pp. 89-92.

[36] G.J.Ríos-Moreno, M. Trejo-Perea, R. Castañeda-Miranda, V.M. Hernández-Guzmán, G. Herrera-Ruiz, Modelling temperature in intelligent buildings by means of autoregressive models, Automation in Construction, 16, (5), (2007),pp.713-722. 
BALKAN JOURNAL OF ELECTRICAL \& COMPUTER ENGINEERING， Vol. 6, No. 3, July 2018

[37] C.E. Ochoa, I.G. Capeluto, Strategic decision-making for intelligent buildings: comparative impact of passive design strategies and active features in a hot climate, Building and Environment, 43, (11), (2008), pp.1829-1839.

[38] O.Woodman, R. Harle, RF-based initialisation for inertial pedestrian tracking, in: H. Tokuda, et al., (Eds.), Pervasive Computing, 7th International Conference, Pervasive 2009, Nara, Japan, May 11-14, 2009, Proceedings. Lecture Notes in Computer Science, 5538, Springer, 2009, pp.238-255.

[39] NanoLOC TRX - High Performance RF Transceiver with Location Awareness and Robust Wireless Communication, Fact Sheet. In http://www.nanotron.com/EN/pdf/Factsheet_nanoLOC-NA5TR1.pdf Nanotron Technologies, 2009.

[40] A.Guillemin, N. Morel, An innovative lighting controller integrated in a selfadaptive building control system, Energy and Buildings, 33, (5), (2001),pp. 477-487.

\section{BIOGRAPHY}

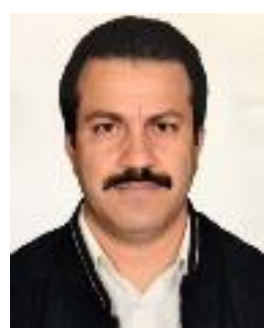

Ahmet ŞENPINAR was born in 1973 in Elazig, Turkey. Author received his MS (Electrical Systems) and $\mathrm{PhD}$ in Solar Energy Systems in 1997 and 2005 respectively from Firat University, Turkey. Currently, he is an assistant professor at College of Technical Sciences, Department of Electronics Technology, Firat University. His research interests are in pv systems and tracking systems. 